\title{
South Asian Declaration-Consensus Guidelines for COVID-19 Vaccination in Cancer Patients
}

\author{
Raja Thirumalairaj ${ }^{1}$ Purvish M. Parikh ${ }^{2} \quad$ Amit Agarwal $^{3}$ Randeep Singh ${ }^{4}$ Arvind Krishnamurthy ${ }^{5}$ \\ Sharad S. Desai ${ }^{6} \quad$ Amita Maheshwari ${ }^{7}$ Prashant Mehta $^{8} \quad$ Abdul Ghafur $^{9} \quad$ S. P. Somashekhar ${ }^{10}$ \\ Ahamed lqbal ${ }^{11} \quad$ Dhairyasheel N. Savant ${ }^{12}$ Syed Md Akram Hussain ${ }^{13} \quad$ Amit Bhatt $^{14}$ \\ Tashi Dendup Wangdi ${ }^{15}$ Jyoti Bajpai ${ }^{16}$ Anantbhushan A. Ranade ${ }^{17} \quad$ K. Govind Babu ${ }^{18}$ Ajay Bapna ${ }^{19}$ \\ Ghanshyam Biswas $^{20}$ Hemant Malhotra ${ }^{21}$ M. Vamshi Krishna ${ }^{22}$ Rajendra Prasad Baral23 \\ Rajesh Vashishtha ${ }^{24}$ Ahmad Javid Safi ${ }^{25}$ Sharmila Agarwal ${ }^{26} \quad$ J. P. Agarwal ${ }^{27}$ Krishna Kumar Rathnam ${ }^{28}$ \\ P. N. Mohapatra ${ }^{29}$ Rajeev Vijay Kumar ${ }^{30}$ Senthil Rajappa ${ }^{31}$ Sewanti Atul Limaye ${ }^{32}$ Amish Vora ${ }^{33}$ \\ Vijay A.P. Reddy ${ }^{34}$ Bhavesh B. Parekh ${ }^{35} \quad$ G. K. Rath ${ }^{36}$
}

${ }^{1}$ Department of Medical Oncology, Apollo Cancer Center, Teynampet, Chennai, India

2Department of Oncology, Integrated Academic Society of Clinical Oncology, Mumbai Oncocare Centers, Mumbai, Maharashtra, India

3 Department of Medical Oncology, BLK Superspecilaity Hospital, Delhi, India

${ }^{4}$ Department of Molecular Oncology Society, Narayana Health, Delhi, India

5 Department of Surgical Oncology, Cancer Institute (WIA), Chennai, India

6 Department of Surgical Oncology, Mahatma Gandhi Cancer Hospital, Miraj,

Maharashtra, India

${ }^{7}$ Divison of Gynecologic Oncology, Department of Surgical Oncology, Tata

Memorial Centre and Homi Bhabha National Institute, Mumbai, Maharashtra, India

${ }^{8}$ Department of Medical Oncology/Hematoncology/BMT, Asian Institute of

Medical Sciences, Faridabad, India

9 Department of Infectious Diseases, Apollo Cancer Institute, Chennai, India

${ }^{10}$ Department of Surgical Oncology, MHEPL, Manipal Comprehensive Cancer

Center, Manipal Hospital, Bengaluru, India

${ }^{11}$ Oncology and Radiotherapy Department, Teaching Hospital, Batticaloa, Sri

Lanka

${ }^{12}$ Department of Surgical Oncology, Asian Cancer Institute, Mumbai,

Maharashtra, India

${ }^{13}$ Department of Radiotherapy, Square Oncology and Radiotherapy Centre,

Dhaka, Bangladesh

${ }_{14}$ Department of Medical Oncology, Avinash Cancer Clinic, Pune, India

15 Oncology Department, JDWNR Hospital and KGUMS, Thimphu, Bhutan

16 Department of Medical Oncology, Tata Memorial Centre, Mumbai,

Maharashtra, India

17 Department of Medical Oncology, Avinash Cancer Clinic, Pune, India

${ }^{18}$ Department of Medical and Pediatric Oncology, St. Johns Medical College

and Hospital, HCG Hospitals, Bangalore, India

19 Department of Medical Oncology, BMCHRC, Jaipur, Rajasthan, India

20 Department of Medical Oncology, Sparsh Hospital and Sum Hospital,

Bhubaneswar, Odisha, India
${ }^{21}$ Department of Medical Oncology, Sri Ram Cancer Center, Mahatma Gandhi Medical College Hospital, Jaipur, Rajasthan, India

22 Department of Medical Oncology and Hematology, Institute of Oncology, AIG Hospitals, Gachibowli, Hyderabad, India

${ }^{23}$ Department of Medical Oncology, Norvic International Hospital and Om

Hospital and Research Center, Kathmandu, Nepal

24 Department of Radiation Oncology, Max Super Speciality Hospital,

Bathinda, Punjab, India

${ }^{25}$ Afghanistan Cancer Foundation and Covid-19 Control Command Centre,

Kabil, Afghanistan

26 Department of Radiotherapy, Jaslok Hospital, Mumbai, Maharashtra, India

27 Department of Radiation Oncology, Tata Memorial Hospital, Homi Bhabha

National Institute, Mumbai, Maharashtra, India

28 Department of Medical Oncology, Meenakshi Mission Hospital and Research

Centre, Madurai, India

${ }^{29}$ Department of Medical Oncology, Apollo Gleneagles Hospital, Kolkata,

West Bengal, India

30 Department of Oncology, BGS Gleneagles Global Hospital, Bangalore, India

${ }^{31}$ Department of Medical Oncology, Basavatarakam Indo American Cancer

Hospital and Research Center, Hyderabad, India

${ }^{32}$ Department of Oncology and Oncology Research, Kokilaben Dhirubhai

Ambani Hospital and Medical Research Institute, Mumbai, Maharashtra, India

${ }^{33}$ Department of Oncology, H.O.P.E. Oncology Cancer Clinic, PSRI Hospital,

New Delhi, India

${ }^{34}$ Department of Radiation Oncology, Apollo Cancer Institute, Hyderabad,

India

35 Department of Oncology, Shalby Cancer and Research Institute,

Ahmedabad, Gujrat, India

${ }^{36}$ National Cancer Center, Delhi, India

Address for correspondence Purvish M. Parikh, MD, DNB, FICP, PhD,

ECMO, CPI, Department of Oncology, Mumbai Oncocare Centers, 1st Floor,

Blue Nile Building, LBS Road, Thane 400601, Mumbai, Maharashtra, India

(e-mail: purvish@mocindia.co.in).

\section{South Asian J Cancer 2021;10:3-8.}

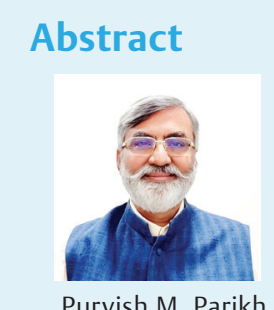

DOI https://doi.org/10.1055/s-0041-1731909 ISSN 2278-330X

How to cite this article: Thirumalairaj R, Parikh P. M, Agarwal A, et al. South Asian Declaration-Consensus Guidelines for COVID-19 Vaccination in Cancer Patients. South Asian J Cancer 2021;10(1):3-8.
We provide the South Asian Declaration, containing the consensus guidelines for coronavirus disease 2019 (COVID-19) vaccination in cancer patients.

Keywords

pandemic, immunity, recommendations, vaccine, Covishield, Covaxin, Sputnik V

\section{(C) 2021. MedIntel Services Pvt Ltd}

This is an open access article published by Thieme under the terms of the Creative Commons Attribution-NonDerivative-NonCommercial-License, permitting copying and reproduction so long as the original work is given appropriate credit. Contents may not be used for commercial purposes, or adapted, remixed, transformed or built upon. (https://creativecommons.org/licenses/by-nc-nd/4.0/).

Thieme Medical and Scientific Publishers Private Ltd A-12, Second Floor, Sector -2, NOIDA -201301, India 


\section{Introduction}

The global coronavirus disease 2019 (COVID-19) pandemic has thrown up unprecedented challenges in every walk of life. ${ }^{1-3}$ Fortunately, technological advances, impressive infrastructure, and past experience laid the foundations for the development of the COVID-19 vaccine at lightening pace., ${ }^{4,5}$ While the drug authorities in many countries have given emergency authorization for several candidate vaccines (based on data from collective experience in more than 100,000 individuals in phase III clinical trials), the social media is buzzing with controversies and questions that remain to be unanswered. Since there is lack of robust efficacy, toxicity, and immunogenicity data amongst cancer patients (because most studies excluded patients with significant co-morbidities including cancer), our expert group of oncologists and infectious disease specialists decided to put together consensus guidelines for the use of COVID-19 vaccine for cancer patients in South Asia.

\section{Overview}

The second wave of COVID-19 is playing havoc across the globe, and especially in South Asia and India. ${ }^{1}$ The concept of herd immunity was based on the premise that any population exposed to the virus (infection) will develop protective IgG antibodies. ${ }^{6}$ While their titers may go down after 3 to 4 months, they continue to be detectable for a couple of years. Also, T-cell immunity was expected to confer protection for 10 years or more (some suggested lifelong). Therefore, recurrence of COVID-19 was predicted to be an exceptional occurrence. ${ }^{7}$ This was supported by the fact that amongst the millions of people infected globally very few developed a second infection and hardly any of it was of a severe nature. Situational modelling also indicated that the pandemic would come under control when $70 \%$ of the population develops immunity (either via natural infection or through vaccination). This is also the rationale on the basis of which United Kingdom enforced strict lockdown and focused on getting $70 \%$ of their population vaccinated. Once this target was achieved, they released the lockdown on April 12, 2021 and normal life is expected to return very quickly. ${ }^{8}$

Indian studies indicate that protective antibodies are prevalent in approximately 30 to $40 \%$ of the population. ${ }^{9}$ Hence vaccination is a top public health priority.

\section{COVID-19 Vaccines and Adverse Reactions}

The COVID-19 vaccines currently available in the region (manufactured in India; Serum Institute of India's Covishield; and Bharat Biotech's Covaxin) are safe for use in all cancer patients. Neither of these are live virus vaccines. Both these vaccines are similar in terms of efficacy and adverse reactions. The third vaccine to receive emergency authorization (Sputnik V through Dr Reddys) is also expected to have similar benefit.

Absolute contraindications include previous history of anaphylaxis; drug reaction causing angio-edema or severe allergic reaction; and previous history of allergy to polysorbitol..$^{10,11}$ In such patients, the vaccine should not be given. These recommendations are unchanged for patients who have cancer.
COVID-19 adverse reactions usually occur in the first 2 to 3 days following administration of the vaccine. ${ }^{12}$ Their severity may be higher after the second dose. Side effects are also more frequent in those who are younger ( $<55$ years).

\section{COVID-19 Vaccination for Cancer Patients}

Our expert group has taken into consideration all available data, scientific rationale, and the landscape of cancer patients in our region. ${ }^{13-25}$ As experienced oncologists and infectious disease specialists we believe that the following consensus guidelines will provide the best protection to cancer patients from the COVID-19 virus pandemic. This is especially important since many of us are facing the second wave/peak of the infections (in February 15, 2021, India had 9,131 new cases [76 deaths]; since then the number of daily new cases has steadily increased to 47,009 [213 deaths] by March 21, 2021). ${ }^{1}$

We followed the Delphi method to arrive at a robust consensus recommendation, using three rounds of voting interspersed with discussion about updated data that became published from time to time. This process was undertaken over a period of 60 days (February to April 2021) ) $^{26}$

\section{For Patients with Solid Tumor Cancers}

All patients with solid tumor cancers are recommended to get the COVID-19 vaccine at the first available opportunity. In case they get infected in the future, vaccination shall help reduce COVID-19 related mortality and severity. Vaccination shall also enable patients to continue their planned anticancer therapy as per schedule without delay or reduction in dose intensity, factors that are vital to ensure optimal benefit. Vaccination should be planned in such a way that the patient's anticancer therapy is not required to be interrupted or postponed. These recommendations are applicable to all solid tumor patients receiving or planned to undergo surgery, radiation therapy, or cancer-directed systemic therapy (chemotherapy, corticosteroids, hormonal therapy, targeted therapy, and immunotherapy).

Under special circumstances, the treating oncologist should take into consideration the following supplementary recommendations on a case-to-case basis ( - Table 1 ). ${ }^{13,15,17}$

Table 1 Guidelines for special circumstances among patients with solid tumor cancers

\begin{tabular}{|l|l|l|}
\hline Sr. no & \begin{tabular}{l} 
Special circumstance \\
\hline 1
\end{tabular} $\begin{array}{l}\text { If cancer Rx is to start } \\
\text { after } 2 \text { wk or more. }\end{array}$ & Give COVID-19 vaccine now. \\
\hline 2 & $\begin{array}{l}\text { If cancer Rx is ending } \\
\text { now or in the near } \\
\text { future. }\end{array}$ & $\begin{array}{l}\text { Give COVID-19 vaccine 2 wk } \\
\text { after the recovery from mye- } \\
\text { losuppression/ end of the Rx. }\end{array}$ \\
\hline 3 & $\begin{array}{l}\text { If cytotoxic chemother- } \\
\text { apy cycles are ongoing. }\end{array}$ & $\begin{array}{l}\text { Time COVID-19 vaccine in } \\
\text { between cycles when the } \\
\text { patient is unlikely to have } \\
\text { myelosuppression. }\end{array}$ \\
\hline 4 & $\begin{array}{l}\text { If there is flexibility in } \\
\text { scheduling COVID-19 } \\
\text { vaccination date. }\end{array}$ & $\begin{array}{l}\text { Plan so that side effects do } \\
\text { not occur on days of adminis- } \\
\text { tration of anticancer Rx. }\end{array}$ \\
\hline 5 & $\begin{array}{l}\text { If immunotherapy or } \\
\text { steroids are to be given } \\
\text { for cancer Rx. }\end{array}$ & $\begin{array}{l}\text { No need to schedule a spe- } \\
\text { cific interval or timing. }\end{array}$ \\
\hline
\end{tabular}


For Patients with Hematological Malignancies $13,14,19,25$

For patients with hematological malignancies, several factors have the potential to influence the effect of COVID-19 vaccination. The main ones include cancer originating in and compromising the immune system; drugs (chemotherapy, targeted therapy, monoclonal antibodies, B/T cell inhibitors, steroids, supportive care) affecting the immune system/immune response.

With so many variables, it is vital to take into consideration the local status of the global COVID-19 pandemic. If the center/region is having few daily new cases, health care infrastructure is not stressed, risk of developing serious COVID-19 illness is low, and the urgency to get vaccinated is not high. Patients with hematological malignancies in such circumstances can wait for the ideal time to get vaccinated (when their immune system is in a position to mount the best response). On the other hand, when the second wave is growing exponentially (current scenario in several urban areas in India), vaccination should be offered to patients at the first available opportunity-even if their immune system is only capable of mounting a muted response.

For patients requiring drugs like rituximab (classic example of lymphocyte-depleting therapy; other examples are blinatumomab, antithymocyte globulin, and alemtuzumab),
COVID-19 vaccination should be delayed till 6 months after completion of therapy if possible. Reconstitution of depleted lymphocytes will be sufficient when ALC (absolute lymphocyte count) $\geq 1.0$ and/or B cell counts $\geq 50$, in which case the vaccine can be given earlier.

For newly diagnosed patients requiring any such medication, anticancer therapy should be given priority over COVID-19 vaccination.

For patients undergoing hematopoietic stem cell transplantation, COVID-19 vaccination is recommended to be administered 6 months later. COVID-19 vaccination may be initiated earlier (after interval of 2-3 months) provided their immune system showed sufficient recovery (peripheral blood B cells > 50; CD4+ T cells >100; and being IVIG independent).

\section{Health Care Community's Opinion and Perception about the Role of COVID-19 Vaccine in Cancer Patients}

We ascertained the current perception amongst community oncologists by conducting an online survey. A total of 101 unique responses (after removing duplicates) were received and analyzed ( - Table 2 ). These answers were taken into consideration to ensure that we develop a consensus

Table 2 Survey results from responding oncologists from South Asia $(N=101)$

\begin{tabular}{|c|c|c|c|c|c|c|}
\hline Sr no. & Question/Statement & Yes & No & Not sure & & \\
\hline 1 & $\begin{array}{l}\text { Are cancer patients more vulnerable to COVID-19 } \\
\text { infection? }\end{array}$ & 88 & 6 & 7 & & \\
\hline 2 & $\begin{array}{l}\text { If infected with COVID-19, do cancer patients have higher } \\
\text { chances of severe infection or death-as compared with } \\
\text { the general population? }\end{array}$ & 85 & 6 & 10 & & \\
\hline 3 & Should all cancer patients take the COVID-19 vaccine? & 65 & 17 & 19 & & \\
\hline 4 & $\begin{array}{l}\text { If a Cancer patient is to receive COVID-19 vaccine, } \\
\text { which of the currently available vaccine (in India) is your } \\
\text { preference? }\end{array}$ & Covishield 61 & Covaxin 15 & 25 & & \\
\hline 5 & $\begin{array}{l}\text { Is the COVID- } 19 \text { vaccine less effective in cancer patients- } \\
\text { as compared with general population? }\end{array}$ & 30 & 20 & 51 & & \\
\hline 6 & $\begin{array}{l}\text { Is special monitoring required after COVID- } 19 \text { vaccina- } \\
\text { tion in cancer patients? }\end{array}$ & 35 & 46 & 20 & & \\
\hline 7 & $\begin{array}{l}\text { What is the best time to get COVID- } 19 \text { vaccine for cancer } \\
\text { patients currently on active anticancer chemotherapy? }\end{array}$ & $\begin{array}{l}\text { Immediately } \\
41\end{array}$ & $\begin{array}{l}\text { After } 1 \text { mo } \\
22\end{array}$ & $\begin{array}{l}\text { After } 3 \text { mo } \\
13\end{array}$ & $\begin{array}{l}\text { After } 6 \text { mo } \\
5\end{array}$ & $\begin{array}{l}\text { Not sure } \\
19\end{array}$ \\
\hline 8 & $\begin{array}{l}\text { Should cancer patients who have recovered from COVID- } \\
19 \text { get vaccination? }\end{array}$ & 84 & 7 & 10 & & \\
\hline 9 & $\begin{array}{l}\text { If a cancer patient who has recovered from COVID-19 } \\
\text { is to be vaccinated, should decision be taken as for a } \\
\text { normal person without co-morbidities? }\end{array}$ & 73 & 17 & 11 & & \\
\hline 10 & $\begin{array}{l}\text { Can patients receiving rituximab be given COVID-19 } \\
\text { vaccine? }\end{array}$ & 39 & 20 & 42 & & \\
\hline 11 & $\begin{array}{l}\text { Is COVID-19 vaccine safe in stem cell transplant } \\
\text { recipients? }\end{array}$ & 26 & 20 & 55 & & \\
\hline 12 & $\begin{array}{l}\text { Can patients with active malignancies be simultane- } \\
\text { ously administered other vaccines along with COVID-19 } \\
\text { vaccine? }\end{array}$ & 29 & 28 & 44 & & \\
\hline 13 & $\begin{array}{l}\text { Should there be any travel restrictions for cancer patients } \\
\text { given all the doses of COVID-19 vaccine? }\end{array}$ & 25 & 64 & 12 & & \\
\hline 14 & $\begin{array}{l}\text { If cancer patient already vaccinated for COVID- } 19 \text { devel- } \\
\text { ops COVID- } 19 \text { infection, should he/she be treated similar } \\
\text { to a noncancer patient? }\end{array}$ & 78 & 06 & 17 & & \\
\hline
\end{tabular}


Table 3 South Asian Declaration-consensus guidelines for COVID-19 vaccination in cancer patients

\begin{tabular}{|c|c|c|c|}
\hline $\begin{array}{l}\mathrm{Sr} \\
\text { no. }\end{array}$ & Consensus statement & $\begin{array}{l}\text { Consensus } \\
\text { agreement }\end{array}$ & Alternate recommendation \\
\hline 1 & Cancer patients are more vulnerable to COVID-19 infection. & $\begin{array}{l}36 / 36 \\
(100 \%)\end{array}$ & None \\
\hline 2 & $\begin{array}{l}\text { If infected with COVID-19, cancer patients have higher } \\
\text { chances of severe infection or death-as compared with the } \\
\text { general population. }\end{array}$ & $\begin{array}{l}35 / 36 \\
(97 \%)\end{array}$ & $\begin{array}{l}\text { Cancer patients without additional comorbidities } \\
\text { have the same chance of severe infection or death } \\
\text { as the general population. }\end{array}$ \\
\hline 3 & $\begin{array}{l}\text { Covid-19 vaccination is contraindicated only in the few } \\
\text { patients who have earlier had severe allergic reactions or } \\
\text { anaphylaxis to substances that constitute part of the Covid- } \\
19 \text { vaccine being considered for administration. }\end{array}$ & $\begin{array}{l}36 / 36 \\
(100 \%)\end{array}$ & None \\
\hline 4 & $\begin{array}{l}\text { All cancer patients should take the COVID-19 vaccine at the } \\
\text { first available opportunity (with few exceptions as men- } \\
\text { tioned-see point } 10 \text { below). }\end{array}$ & $\begin{array}{l}36 / 36 \\
(100 \%)\end{array}$ & None \\
\hline 5 & $\begin{array}{l}\text { Cancer patients should receive whatever COVID-19 vaccine } \\
\text { is available (none of the approved vaccines are live). All } \\
\text { vaccines have similar efficacy in preventing serious infection, } \\
\text { need for intensive care, and death. }\end{array}$ & $\begin{array}{l}36 / 36 \\
(100 \%)\end{array}$ & None \\
\hline 6 & $\begin{array}{l}\text { COVID-19 vaccine is likely to be less effective in cancer } \\
\text { patients-as compared with general population. Still all can- } \\
\text { cer patients should be vaccinated-because some immunity } \\
\text { is better than no immunity. }\end{array}$ & $\begin{array}{l}34 / 36 \\
(94 \%)\end{array}$ & $\begin{array}{l}\text { COVID-19 vaccine is equally effective in cancer } \\
\text { patients as in persons without cancer. }\end{array}$ \\
\hline 7 & $\begin{array}{l}\text { Special monitoring is usually not required after COVID-19 } \\
\text { vaccination in cancer patients. Some exceptions exist that } \\
\text { will be decided by your oncologist. }\end{array}$ & $\begin{array}{l}35 / 36 \\
(97 \%)\end{array}$ & $\begin{array}{l}\text { Cancer patients getting COVID-19 vaccination } \\
\text { must be closely monitored as those on active } \\
\text { treatment are prone to neutropenia or infections } \\
\text { and may lead to adverse effects. }\end{array}$ \\
\hline 8 & $\begin{array}{l}\text { For cancer patients currently on active anticancer chemo- } \\
\text { therapy, the best time to get COVID-19 vaccine is to be } \\
\text { decided by the treating oncologist. }\end{array}$ & $\begin{array}{l}36 / 36 \\
(100 \%)\end{array}$ & None \\
\hline 9 & $\begin{array}{l}\text { Cancer patients, who have recovered from COVID-19, } \\
\text { should also take the vaccine as soon as possible. Their } \\
\text { vaccination timing should be decided by the treating } \\
\text { oncologist based on overall health status and all relevant } \\
\text { co-morbidities. }\end{array}$ & $\begin{array}{l}36 / 36 \\
(100 \%)\end{array}$ & None \\
\hline 10 & $\begin{array}{l}\text { Cancer patients receiving drugs like rituximab (monoclonal } \\
\text { antibodies directed against lymphocytes) or undergoing } \\
\text { hematopoietic stem cell transplants should discuss with } \\
\text { their treating oncologist regarding the safest time for receiv- } \\
\text { ing the COVID-19 vaccine. }\end{array}$ & $\begin{array}{l}36 / 36 \\
(100 \%)\end{array}$ & None \\
\hline 11 & $\begin{array}{l}\text { If necessary, patients with active malignancies can simulta- } \\
\text { neously be administered other vaccines along with COVID- } \\
19 \text { vaccine-as long as it is not a live vaccine. }\end{array}$ & $\begin{array}{l}34 / 36 \\
(94 \%)\end{array}$ & $\begin{array}{l}\text { The gap between different vaccine administration } \\
\text { should be } 2 \text { wk for killed vaccines and } 4 \text { wk for live } \\
\text { vaccines. }\end{array}$ \\
\hline 12 & $\begin{array}{l}\text { When administering more than one vaccine, it is advisable } \\
\text { to have a gap of } 1 \text { wk between doses of different vaccines. }\end{array}$ & $\begin{array}{l}34 / 36 \\
(94 \%)\end{array}$ & $\begin{array}{l}\text { Gap between doses of different vaccines should be } \\
4 \text { wk. }\end{array}$ \\
\hline 13 & $\begin{array}{l}\text { Once they have completed } 2 \mathrm{wk} \text { following their last dose of } \\
\text { COVID- } 19 \text { vaccines, cancer patients should be subject to the } \\
\text { same travel restriction like any other normal person. }\end{array}$ & $\begin{array}{l}36 / 36 \\
(100 \%)\end{array}$ & None \\
\hline 14 & $\begin{array}{l}\text { If a cancer patient, who has already been vaccinated for } \\
\text { COVID-19, now develops COVID-19 infection, he/she should } \\
\text { be treated as having higher risk of complications, severity or } \\
\text { death from the infection. }\end{array}$ & $\begin{array}{l}33 / 36 \\
(92 \%)\end{array}$ & $\begin{array}{l}\text { 1. Vaccinated cancer patients who develop COVID- } \\
19 \text { infection have the same risk of complications } \\
\text { and death as other noncancer patients. } \\
\text { 2.Vaccinated cancer patients developing COVID } 19 \\
\text { infection must be treated as per standard existing } \\
\text { hospital protocols but closely monitored for higher } \\
\text { complication rates. }\end{array}$ \\
\hline
\end{tabular}


statement that will specifically help in improving, understanding, and optimizing COVID-19 vaccination for cancer patients in the community.

This survey analysis documents the varied opinions held by oncologists-especially questions $5,6,7,10,11$, and 12 . Clearly better understanding of upto date information and systematic application of current recommendations was missing. Our consensus guidelines will go a long way in giving confidence to the health care professionals in providing optimal care to their cancer patients with respect to getting the best immunity against COVID-19.

\section{Consensus Guideline Statement for COVID-19 Vaccination of Cancer Patients}

The South Asian Declaration of the Consensus Guidelines for COVID-19 vaccination in cancer patients are shown in - Table 3. These were arrived at using the Delphi methodology and included three rounds of voting. The entire process took 60 days including online group discussions to evaluate evolving data that became vailable from time to time.

Updated document shall be available online from concerned medical associations and societies' websites from time to time. In the meantime, we urge all health care professionals and patients to use these consensus guidelines for all patients with active or treated cancer-based on emergency use authorization provided by drug authorities.

\section{Supplementary Considerations}

1. Patients with cancer should not be forced to decide between taking the COVID-19 vaccine and participating in cancer clinical trials.

2. Additional doses (beyond standard authorization) are not recommended.

3. If cancer patients were administered COVID-19 vaccine during a period of immunosuppression, they should not undergo revaccination after recovery from their immunosuppressed status.

4. Whether a booster dose will be required or not shall only be ascertained in the future. Currently no evidence exists regarding this question.

5. Patients who have recovered from COVID-19 infection should also be offered vaccination. There is no recommendation for a minimum interval between infection and vaccination in recovered individuals.

6. Recovery from acute COVID illness is based on resolution of fever for at least 24 hours (without antipyretic medication) and with improvement of all other COVID-19 related symptoms.

7. If time to recovery from COVID-19 is beyond the scheduled subsequent dose, it should be postponed till recovery. When this happens, it is not necessary to restart the vaccination schedule.

8. There is no data that antibody titer correlates with immunity and protection against COVID-19 infection. Hence vaccination should be done for cancer patients even if they have high levels of COVID-19 IgG antibodies.
9. Patients with breast cancer should receive COVID-19 vaccine on the opposite arm. Vaccination can rarely cause enlargement of lymph nodes in the axilla which might be mistaken for recurrence of the cancer on mammography or clinical examination.

Conflict of Interest

None declared.

\section{References}

1 Worldometer. COVID-19 coronavirus pandemic. Available at: https://www.worldometers.info/coronavirus/. Accessed April 16, 2021

2 Purvish P, Prashant M, Shyam A. Important COVID-19 updateNew life-threatening syndrome in pediatric patients? Int J Mol Immuno Oncol 2020;5(2):42-43

3 Parikh PM, Mehta P, Krishna MM, Babu GK. Clinical trials facing serious adverse events during the ongoing COVID-19 pandemic. Indian J Med Paediatr Oncol 2020;41:127-131

4 Mehta P, Parikh P, Aggarwal S, et al. Has India met this enemy before? From an eternal optimist's perspective: SARS-CoV-2. Indian J Med Sci 2020;72:8-12

5 Parikh P, Singh R. Hot race for COVID-19 vaccines - Light at the end of the tunnel just got brighter. Int J Mol Immuno Oncol 2021;6(1):1-3

6 World Health Organization. Coronavirus disease (COVID19): Herd immunity, lockdowns and COVID-19. Available at: https://www.who.int/news-room/q-a-detail/herd-immunitylockdowns-and-covid-19?gclid=Cj0KCQjwyN-DBhCDARIsAFOELTmy-hL7heEZS3HTnwXonWQwTgsp0j9yvs7ijoG4pdZUP5vp-u_Q4aUaAjwUEALw_wcB\#. Accessed on: April 16, 2021

7 Chakrabarti SS, Kaur U, Singh A, et al. Of cross-immunity, herd immunity and country-specific plans: experiences from COVID-19 in India. Aging Dis 2020;11(6):1339-1344

8 BBC News. England's lockdown to ease as planned on 12 April. Available at: https://www.bbc.com/news/uk-56641596. Accessed on: April 16, 2021

9 Chandrashekhar V. Herd immunity? India still has a long way to go, scientists say. Science 2020;370(6516):513

10 Banerji A, Wickner PG, Saff R, et al. mRNA vaccines to prevent COVID-19 disease and reported allergic reactions: current evidence and suggested approach. J Allergy Clin Immunol Pract 2021;9(4):1423-1437

11 Sokolowska M, Eiwegger T, Ollert M, et al. EAACI statement on the diagnosis, management and prevention of severe allergic reactions to COVID-19 vaccines. Allergy 2021;(e-pub ahead of print). doi: 10.1111/all.14739

12 Kaur RJ, Dutta S, Bhardwaj P, et al. Adverse events reported from COVID-19 vaccine trials: a systematic review. Indian J Clin Biochem 2021;(e-pub ahead of print). doi: 10.1007/ s12291-021-00968-z

13 Available at: https://www.mskcc.org/coronavirus/covid-19vaccine. Accessed on: April 16, 2021

14 American Society of Hematology. Available at: https://www. hematology.org/covid-19/ash- astct-covid-19-and-vaccines

15 American Society of Clinical Oncology. Available at: https://www.asco.org/asco-coronavirus- resources/covid19-patient-care-information/covid-19-vaccine-patientscancer. Accessed on: April 16, 2021

16 Parikh PM, Bapna A, Krishna MV, Mehta P, Aggarwal S, Gulia A. COVID-19 testing in India in comparison to the rest of the world. If Indian testing strategy was replicated in the other top 15 COVID-19 affected countries in the world, 
the status would be startlingly different. Indian J Med Sci 2020;72(2):107-109

17 ESMO Cancer Patient Management During the COVID-19 Pandemic. Available at: https://www.esmo.org/guidelines/ cancer-patient-management-during-the-covid-19-pandemic. Accessed April 10, 2021

18 Parikh P. COVID-19 pandemic: contrast between SAARC countries and Western World. 2020. Available at: https://www. m3india.in/contents/editor_pick/136721/covid-19-pandemic-contrast-between-saarc. Accessed April 12, 2020

19 Tartarone A, Lerose R. COVID-19 and cancer care: what do international guidelines say? Med Oncol 2020;37(9):80

20 Parikh P, Mehta P, Bansal S, et al. Protecting health-care professionals and workers (other than COVID-19 management facilities) from contamination during COVID-19 pandemic. Indian J Med Sci 2020;72:3-4

21 Miyashita H, Mikami T, Chopra N, et al. Do patients with cancer have a poorer prognosis of online April 21, 2020.
COVID-19? An experience in New York City. Ann Oncol 2020;31(8):1088-1089

22 Gundavda MK, Gundavda KK. Cancer or COVID-19? A review of guidelines for safe cancer care in the wake of the pandemic. SN Compr Clin Med 2020;(e-pub ahead of print). doi 10.1007/s-42399-020-00632-2

23 prpt . Monin-Aldama 1, Giang AG, Munoz-Ruiz M, McKenzie DR, del Barro IM, et al. Interim results of the safety and immune-efficacy of 1 versus 2 doses of COVID-19 vaccine BNT162b2 for cancer patients in the context of the UK vaccine priority guidelines. doi: https://doi.org/10.1101/2021.03.17.2 1253131(MedRxiv)/prpt

24 Curigliano G. Cancer patients and risk of mortality for COVID19. Cancer Cell 2020;38(2):161-163

25 Kamboj M, Shah MK. Vaccination of the stem cell transplant recipient and the hematologic malignancy patient. Infect Dis Clin North Am 2019;33(2):593-609

26 Hasson F, Keeney S, McKenna H. Research guidelines for the Delphi survey technique. J Adv Nurs 2000;32(4):1008-1015 